\title{
AUTÓEMBLÉMÁK AZ ÁLLATVILÁGBÓL
}

\author{
Dömötör Csaba \\ egyetemi docens, Miskolci Egyetem, Gép-és Terméktervezési Intézet \\ 3515 Miskolc, Miskolc-Egyetemváros, e-mail: machdcs@uni-miskolc.hu
}

\begin{abstract}
Absztrakt
A természetröl másolni hatáselveket és hatáshordozókat vagy akár konkrét formát, konstrukciót, színezetet vagy éppen mintázatot legtöbbször kifizetödö vállalkozás. A régröl ismert, így az emberek tudatalattijában gyökerezö alakzatok használatával a vásárlók szemében tartósságot sugárzó, bizalmat ébresztố, vagy egyszerüen csak használatra alkalmas és tetszetös forma-illetve színvilágú termékeket tervezhetünk. Ez abban az esetben is igaz, ha a fellelt természeti analógia nem a termékben magában köszön vissza, hanem az azt forgalmazó cég emblémájának meghatározó grafikai eleme. Ez a cikk az autóipari vállalatok emblémáiban fellelhetö természeti motivumokat rendszerezi és bemutatja ezek márkaarculatban betöltött szerepét.
\end{abstract}

Kulcsszavak: természeti analógiák, autóipar, logó, embléma, márkaarculat

\section{Abstract}

Copying principles and functions from nature, or even a particular shape, construction, colouration or pattern is most often a rewarding business. By using shapes that have long been known and thus rooted in human subconsciousness, users can design products that show durability, create confidence or simply be usable and appealing in shape or colour. This is true even if the natural analogy found is not due to the product itself, but to the graphic element of the logo of the company. This article systematizes the natural motifs found in the emblems of the automotive industry and illustrates their effects in branding.

Keywords: natural analogies, automotive, logo, emblem, branding

\section{Bevezetés}

Egy vállalat vagy márka piaci helyzetének szempontjából kiemelt jelentőségü, hogy azt a vásárlók vagy ügyfelek könnyen felismerjék, illetve meg tudják különböztetni a piaci versenytársaktól. Ennek egyik kiváló eszköze a brandet egyértelműen beazonosítani képes, jól felismerhető és megjegyezhető, egyedi jel, mely ily módon a márka arculati alapeleme lehet. Ezeknek a marketing szempontból frontvonalban lévő jelvényeknek a jó megválasztása gyakran döntő fontosságú a piaci helyzet megalapozásához. A továbbiakban azt vizsgáljuk, hogy a természetből adaptált motívumokkal milyen üzeneteket igyekeznek átadni a gyártók.

\subsection{Természetközeli design}

Az emberiség fejlődéstörténetét vizsgálva megállapítható, hogy az ember jóval több időt töltött a természet közelében, mint attól eltávolodva. Az új impulzusok, társadalmi hatások vagy megváltozott viselkedésformák ellenére ezért ösztönszerüen a felszínre kerülnek az őseink által korábban megszerzett tapasztalatok. Ezzel indokolható az is, hogy például általános figyelemfelkeltésre az egyik 
legalkalmasabb választás a sárga-fekete párosítás. Ennek legfő́bb oka, hogy kiemelkedő színkontrasztja miatt az élővilág is gyakran felhasználja, mint vizuális jelzést, így lesz a mesterségesen létrehozott tárgyak vagy terek egyik leghatékonyabb figyelemfelkeltő eszköze [5].

Hasonlóan természeti alapelveket vagy jelenségeket követve akár formatervvel, akár egy jól megtervezett emblémán keresztül is lehet különböző tulajdonságokat sugallni. Mivel a jó tervező általánosan a tartalom és a forma összhangjára törekszik, gyakori tervezési szempont, hogy nem elég például áramvonalasnak/gyorsnak/megbízhatónak/strapabírónak lenni, annak is kell látszani. Az emblémák pedig jó eszközei az efféle indirekt közléseknek. Az általuk nonverbális úton átadott üzenet pedig úgy juthat el a vásárlóig, mintha ez az ő saját önálló felismerése lenne, így az benne jó eséllyel megkérdőjelezhetetlen információként fog lecsapódni.

\subsection{Természetközeli autóemblémák csoportosítása}

Az autógyártók többsége nagy múltra visszatekintő cégcsoport részeként müködik, így sok esetben egy-egy márka emblémája a tulajdonviszonyokat, a piacot, a divatot vagy éppen a felhasználói igényeket követve több változáson is átesett már napjainkig. Ezek a változások legtöbb esetben megtartják a fő motívumokat, de néhány esetben radikálisan új dizájnt hoznak. Jelen cikk többségében napjaink aktuális autóemblémáit dolgozza fel, de néhány - föleg magyar vonatkozású esetben visszatekint az elmúlt idők emlékeire is. Az természetből adaptált emblémák csoportosítására több lehetőség is kínálkozik, de esetünkben a fö formai elem, mint meghatározó motívum jelenti a besorolási szempontot.

Jelen cikk alaptémáját a természetben fellelhető motívumokat alkalmazó autóemblémák adják. Ezeket közelebbről megvizsgálva a 2. fejezetben részletesen ismertetett kategóriák alkothatók. Ezek között jellemzően az állatvilágból származó analógiákkal találkozhatunk, de az autógyártás történetében rendszeresen visszatérő motívum volt a jellegzetes, masszív, fényes leveleiröl ismert növényből, vagyis a babérágakból font koszorú is. Az állatvilágból származó gyakori példák között említhetjük repüléshez kapcsolódó szárnyakat és madarakat, de kiemelt szerep jut a közlekedésben jól bevált lovaknak is. Gyakran alkalmaznak a gyártók ragadozókat, de a mitológiai lényekre is több példát találunk. A növényevő állatok közül a kérődzőkre utaló motívumok alkotnak még egy nagyobb halmazt, míg a sort a csúszómászók kategóriája zárja.

\section{Természetes szimbólumok}

Mielőtt részletesebben megvizsgálnánk a felsorolt csoportokat érdemes számba venni a téma magyar vonatkozásait is. Hazánk a saját fejlesztésü és nagy szériás személyautógyártás terén sosem jutott világpiaci szerephez, viszont kiemelkedő gazdasági eredményeket értünk el a teherautó és buszgyártás szegmensében, ahol a hazai ipar legfontosabb szereplői a Ganz, a Rába és az Ikarus voltak.

A téma kapcsán meg lehet említeni a Puli kétüléses mủanyag karosszériás városi kisautót (1.a ábra), amit 1986 és 1998 között gyártott a hódmezővásárhelyi Hódgép [6]. Ugyanígy magyar fejlesztésü és gyártású a 2012-ben bemutatott Komondor (1.b ábra), ami a Gamma Müszaki Zrt. könnyü-páncélvédettséggel rendelkező katonai vegyi-felderítő jármüve [7]. Kapcsolópontot jelent, hogy mindkét jármü esetén ősi magyar kutyafajtát választottak névadóként, miközben a kutya más gyártók emblémáiban, márka vagy típusneveiben kifejezetten ritkán szerepel, holott ezek az állatok a hüség, odaadás, erő és kitartás szimbólumai. 


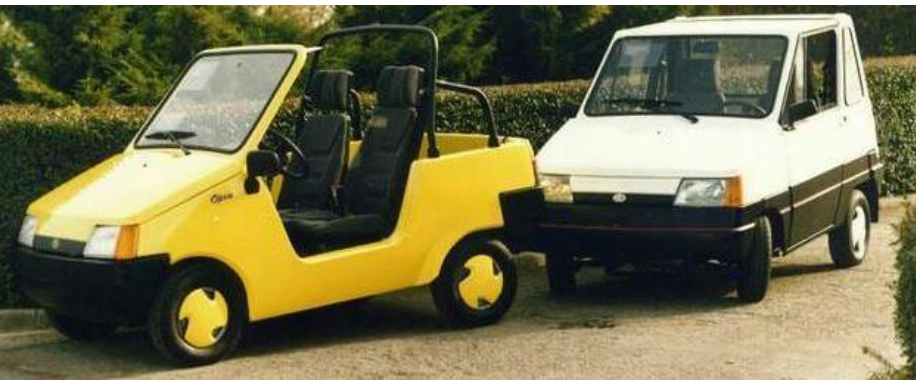

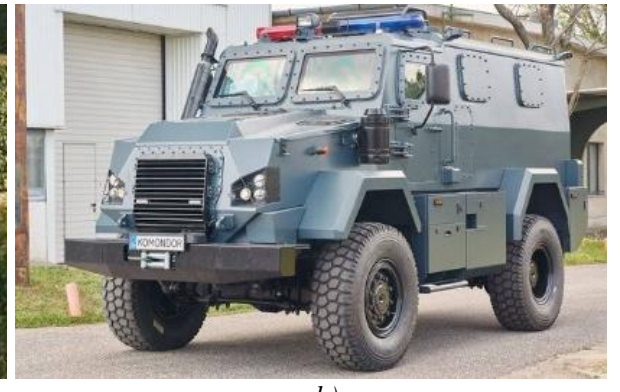

b)

1. ábra. A magyar Puli kisautó (a) és Komondor katonai terepjáró (b)

\subsection{Növények}

Az autóemblémák területén a növényvilág arányában jóval kevesebb példát szolgáltat, de van egy motívum, amit több gyártó is elöszeretettel alkalmazott már jelvényeiben. Ez pedig a babér, ami azonban nem természetes állapotában hordoz számunkra üzenetet, hanem egy ember által alkotott, győzelmet és dicsőséget szimbolizáló tárgyban. Ez az örökzöld növényből fonott koszorú már az ókori görögök óta a hervadhatatlan érdemek jutalma. Érdekesség, hogy az ilyen fejdíszeket földrajzi adottságoktól függően helyenként készítették mandulafenyőből, zellerből vagy olajágból is.

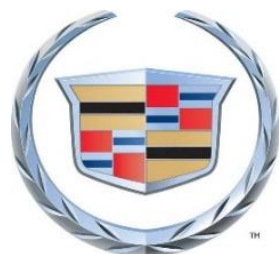

a)

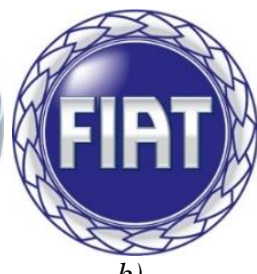

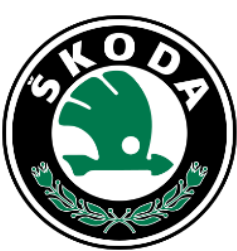

c)

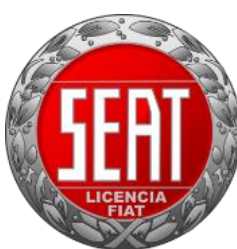

d)

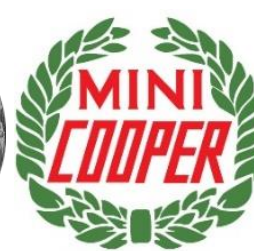

e)

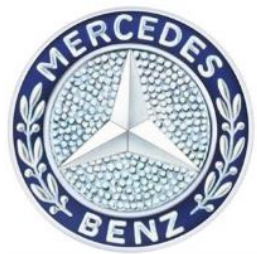

f)

Az autóversenyeken elért győzelmek kiemelkedő reklámértéke miatt a győzelmi koszorú használata az autózás kezdetén jóval népszerübb volt, aztán lassan kikopott a használatból. Ennek megfelelően 2. ábrán bemutatott márkajelzések közül jelenleg egyik sem aktuális emblémája az adott gyártónak. Ezek közül az eltünésük fordított sorrendjében elsőként szereplő Cadillac embléma a legfiatalabb, amiről egyébként 2014-ben tünt el a babérkoszorú.

\subsection{Szárnyak, madarak}

Minden idők leggyakrabban használt szimbólumai a szárnyak, melyek a gyártó magasságok felé való törekvését mutatják. Sokszor csak keretbe foglalnak egy központi feliratot vagy alakzatot, máskor viszont ők maguk jelentik a fö motívumot. A 3. ábrán látható, hogy esetenként az embléma már-már anatómiai pontossággal követi a szárny alakját, de többségében csak stilizált módon jelenik meg.

A 3. ábrán balról jobbra és fentről lefelé haladva elsőként a brit Bentley szárnyas „B” betűjének részletgazdag kidolgozásában az is megfigyelhető, hogy egyedülálló módon itt a madarak faroktollai is megjelennek. A gyártó kommunikációja szerint egyébként a madárszárnyakkal a sebességet és a függetlenséget kívánják szimbolizálni. Sokkal inkább szimbolikus a Mazda logója (3.b ábra), amiben a márkanév "M" betűje fedezhető fel, de a belül látható "V" alak egy távolban repülő madár sziluettjét 
idézi, ami a vállalat szárnyainak kitárását szimbolizálja a jövő irányába. Az embléma egyúttal a márkára jellemző kreativitást, küldetéstudatot és vitalitást is hivatott megjeleníteni. A sorban következő Mini szárnyaló keréktárcsa-motívuma önmagában is beszédes autóipari utalás, ami eredetileg a Morris emblémákban tünt fel, de a mai napig használják. A 3.d-e ábrák a Hyundai egyegy típusának egyedi azonosító plakettjei. Az első egy lekerekített trapézban szárnypárt, illetve szárnyaló madarat ábrázoló embléma kizárólag a gyártó Equus típusnéven futó luxusautóin jelenik meg, ahogyan a Genesis névre keresztelt prémium márkájának típusait is egyedi jelzéssel látja el a koreai vállalat.

Az 3.f és 3.h ábra két brit autógyár logóit mutatja. A legendás és sikeres Aston Martin ugyanúgy szárnyakkal övezi a logóját, mint az egyedi, régi stílusú, de modern müszaki megoldásokat használó autókat építő Morgan. Középen a 3.g ábrán a magyar Ikarus autóbuszok régi logója látható, alsó részén szárny motívummal, ami a névadó Ikaroszt idézi, hiszen a görög mitológia szerint ő volt az első ember, aki repült. Megtestesítette az újdonság iránti nyitottságot, az emberi nagyratörés vágyát, a félelem leküzdését és azt a gondolatot, hogy az emberi találékonyság csodákra képes. De ugyanakkor Ikarosz a lázadás, a szófogadatlanság és a kíváncsiság szinonimája is lett, mely tulajdonságok egy innovatív gyártót sokszor visznek előre.

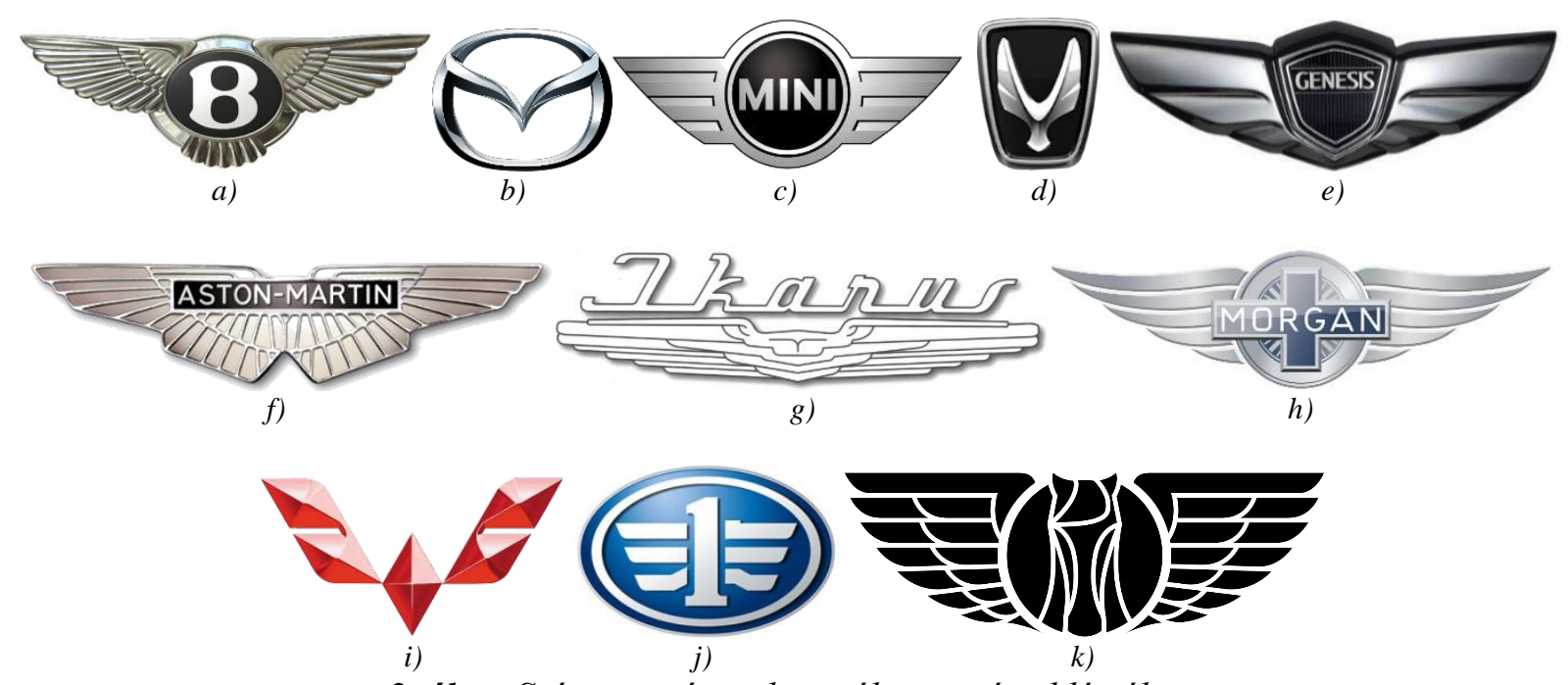

3. ábra. Szárny motívum használata autóemblémákon

Az 3. ábra harmadik sorában kínai gyártók emblémáit találjuk. Az öt vörös gyémántból formázott szárnyaló madár sziluett a főként egyterü autók gyártására szakosodott SAIC Wuling Automobile jelképe, mely mára a General Motors csoport tagja. Az aszimmetrikus szárnyas 1-es embléma Kína 1953-ban alapított legnagyobb teherautó gyártójának, a Jiefang - FAW csoportnak gyártmányait jelöli. Végül az egyik legsikeresebb kínai gyártó a Geely tulajdonában álló $\mathbf{L E V C}$ (London Electric Vehicle Company) lófejet körülvevő szárnyas emblémája következik, ami nem egyértelmủen pegazus, inkább a szárnyalást és nemességet kívánja önmagába ötvözni. A vállalat a londoni elektromos taxik gyártásáról tárgyalt a brit kormányzattal, bár ezen járművek elterjedése még várat magára. Viszont az anyacég szerteágazó ambícióit ismerve - a WTCR-ben is eredményesen versenyeznek - nem zárható ki, hogy Londonban hamarosan egyre több ilyen autó segíti majd a levegőszennyezés visszaszorítását.

Formája miatt átmenetet képez a szárnymotívumok és a madáralakok között a Jeep márka 4.a ábrán bemutatott Trailhawk felszereltségủ modelljein megjelenő sólyom emblémája. A kiváló 
látásáról is ismert, égbolton köröző ragadozómadár sziluettje azt közli a felhasználóval, hogy nyugodtan elindulhat bármilyen terepen, mert meg fogja találni a megfelelö ösvényt, amin a márka jelenleg kapható legjobb terepképességekkel rendelkező modellje biztosan elboldogul majd.

Látható tehát, hogy kizárólag szárnyak ábrázolása helyett a teljes madár képe is megjelenhet az emblémákon. Az üzenet hasonlít az előzőekhez, de az ilyen jelvények már a madarak által megtestesített aerodinamikus szépséget és funkcionalitást is közvetítik. Gyakori a sas, mint szimbólum. Ez a madarak, valamint a levegő és égbolt királyának tekintett ragadozó a bátorság, határozottság, erő és nagyság üzenetét hordozza. Ugyanígy a vándorsólyom is népszerü választás a szupersportautó gyártók körében, ami nem véletlen. Vadászat közbeni kontrolált zuhanásakor $400 \mathrm{~km} / \mathrm{h}$ feletti csúcssebességet képes elérni, amivel a Föld leggyorsabb állatának számít.

Az új-zélandi Saker Sports Cars vállalat régi logója még zuhanórepülésben ábrázolta a vándorsólymot, amivel sokkal inkább kifejezte a sebességet, de a jelenlegi dinamikus vonalvezetésü sólyomfej is kifejezetten áramvonalas hatást kelt. A Rossion amerikai és az Arash brit szupersportautókon egy prédájára lecsapó vadászsólyom képe üzeni a járműveik formatervében is közvetített agresszív megjelenést. Az Isdera (Ingenieurbüro für Styling, Design und Racing) német cég egyedi építésü sportautóinak logóján hasonlóan vadászat közben, viszont már egy sas látható világoskék mezőben.

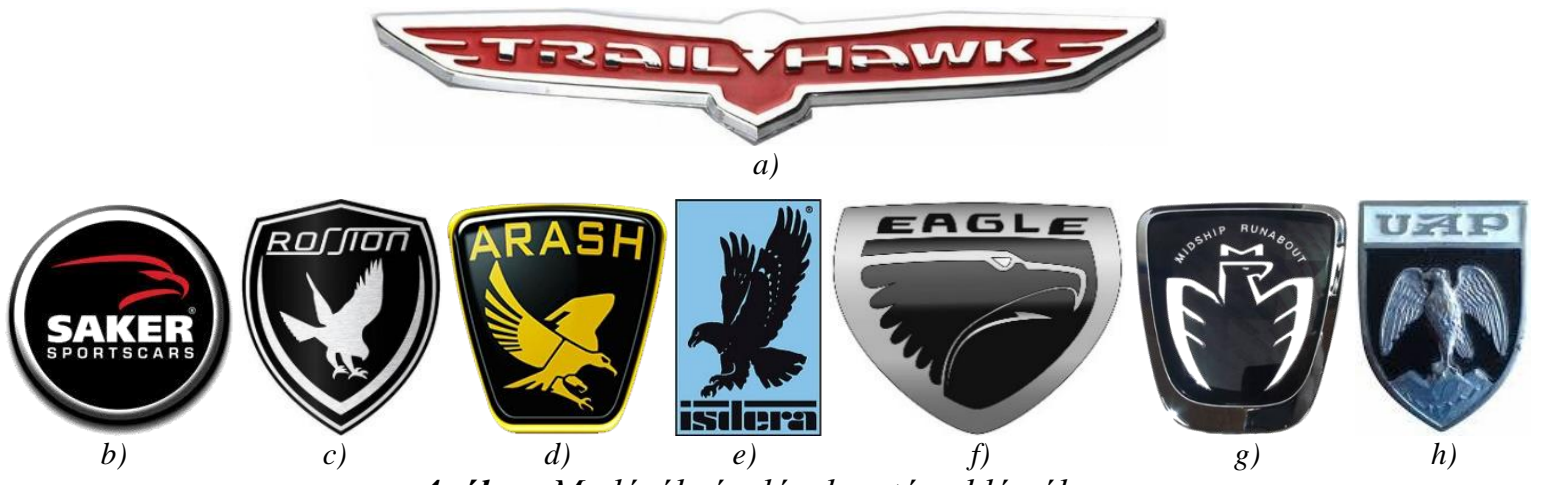

4. ábra. Madárábrázolások autóemblémákon

Eagle márkanéven, sas fejet ábrázoló emblémával értékesített személyautókat a Chrysler, de ezen autók forgalmazása már megszünt. Ugyanígy 2007-ben befejeződött a gyártása a Toyota MR2 típusnevü, kétüléses középmotoros sportautójának, ami a 4.g ábrán szereplő egyedi emblémát viselte. A Toyota közleménye szerint ez egy „madár, ami az evolúción át létrejött aerodinamikus szépséget reprezentálja”, de a tulajdonosok ironikusan csak „visító csirkének” titulálják a motívumot. A régi jelvények sorában érdemes még megemlíteni a hazánkban régóta jól ismert Dacia 1978-ig viselt logóját, ami Románia hagyományos jelképét és címerállatát, vagyis egy kitárt szárnyú sast ábrázol. A pajzs tetején olvasható UAP mozaikszó az „Uzina de Autoturisme Pitesti” vagyis Pitesti Autógyár rövidítése.

\subsection{Lovak}

Szintén gyakran használt autóipari jelkép a ló. Az ezekben a nemes állatokban megtestesülő tulajdonságok legtöbbünkben pozitív érzéseket váltanak ki és mindemellett szorosan kötődnek az emberiség korai és jelenlegi mobilizációjához is. A vadlovakhoz kapcsolódik a szabadság érzése, valamint az erö, 
sebesség és dinamizmus is eszünkbe juthat róluk. Az igavonó fajták leginkább a kitartásukról ismertek, de minden ló sajátsága az erős jellem is. Mindezek olyan jellemzők, melyeket egy autótól is elvár a vásárló, tehát marketing szempontból jó választás már az emblémával is ezeket ígérni.

A 3.k ábrán már láthattuk a lovat, mint szimbólumot, de egy másik kínai gyártó, a GM csoportba tartozó Baojun szintén ennek az állatnak a stilizált képét használja autóin (5.a ábra). A 2019-ben bevezetett gyémántot formázó rombuszalakba integrált lófej eredetileg jóval realisztikusabb ábrázolással egy pajzson szerepelt, hasonlóan az IKCO nevü iráni gyártó jelenlegi emblémájához. A lovagok korszakából ismert pajzzsal az állat nemessége még hangsúlyosabb.

A piros alapon fehér lófej az indiai Eicher motorkerékpár és teherautógyár emblémája (5.c ábra), mely grafikai elemeivel lobogó lósörényt idézve sugall lendületet. Nyomatékosabban utal a sebességre az egyik legismertebb lovas autóembléma, amit a Ford Motor Company Mustang névre keresztelt izomautóin találunk. Már a nevet is az Észak-Amerikába behozott spanyol lovak elvadult utódjának tekinthető kistestű, erős testfelépítésű lófajtától kölcsönözték, amit a jól megjegyezhető vágtázó lóalak is szemléltet (5.d ábra). Hasonlóan futó lovat jelenít meg a világ egyik legjelentősebb nehéztehergépkocsi-gyártójának logója is. A Kamaz gyártmányain a mezőn futó lóval az autóik erősségét és mozgékonyságát kívánják kiemelni. A nemzetközi piacon elismert és például a Dakar-rallye kihívásain is sikeres gyártó Oroszország legnagyobb jármüipari vállalata.

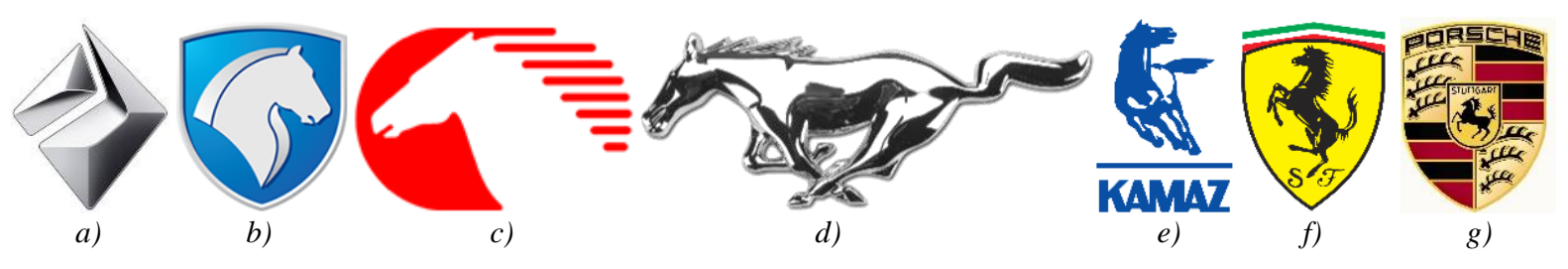

5. ábra. Lovak megjelenitése az autók emblémáin

Még inkább az erő és dinamizmus dominál egy ágaskodó ló látványában. Nem véletlen tehát, hogy a Ferrari olasz nemzeti színekkel díszített és Enzo Ferrari szülővárosának, Modenának sárga színét viselő pajzsán is egy ilyen magabiztosságot sugárzó állat szerepel (5.fábra). Mindez Baracca első világháborús olasz pilóta emlékét idézi, aki mindig egy fekete ágaskodó lovat festetett repülőgépe oldalára [1]. A „szerencsét hozó” jelkép meglehetősen hasonlít a Porsche sportkocsik emblémájának közepét díszítő és eredetileg a gyártó székhelyének, Stuttgart városának címerében szereplő ágaskodó lófigurára, mely testtartásával az előre rugaszkodást fejezik ki. A pajzson látható stilizált szarvasagancsok pedig a történelmi Baden-Württemberg tartomány címerállataira utalnak, ahogyan a vörös és a fekete sávok is ezen tartomány hagyományos színei [1]. Összességében megállapítható, hogy a lovak nemcsak az önmagukban hordozott üzenet lévén, de az ösi címerekben megnyilvánuló történelmi jelentőségük folytán is fontos jelképei lettek az autógyártóknak.

\subsection{Ragadozók}

A lovakkal ellentétben a ragadozó állatok legtöbb esetben nem kifejezetten együttmüködő partnereink. Hatékony vadászkészségük és intelligenciájuk miatt viszont mindig is tisztelet övezte az emberre is veszélyes nagymacskákat vagy éppen farkasokat. A ragadozókra egységesen jellemző az irányítás készsége, az uralom akár erőszakos megszerzése. Magabiztos kiállásuk példája ősi, vad ösztönöket hívhat elő az emberben is. Ha a történelem során bárki birtokolni és irányítani tudta öket, arról mármár földöntúli erőt feltételeztek szemlélöik. Emiatt is váltak a magabiztosság és hatalom jelképeivé. Az oroszlánoknak ezen felül is kiemelt szerep jut, hiszen már az alacsony frekvenciás infra 
hangtartományokat tartalmazó morgásuk és üvöltésük is tekintélyt parancsol. Mindemellett a dús sörényü hímek sziluettje régi királyi jelkép is.

A talán legismertebb oroszlános autójelvényt a Peugeot gyártmányain találjuk (6.a ábra). A heraldikából visszaköszönő és a címertan normáit betartva balra néző két lábon álló állat ebben a testhelyzetben már szinte emberi alakot ölt. Bár ez az embléma is többször változott 1850-es megjelenése óta, jelentése ugyanaz maradt. A cég első székhelyének tartományi címeréből származó tradicionális megjelenésével minőséget, megbízhatóságot, hosszú élettartamot fejeznek ki általa. Ehhez hasonlít a General Motors ausztrál Holden márkájának emblémájában található kereket tartó üvöltő oroszlán (6.bábra). Egy ős fabula szerint a kerék, mint találmány ötlete az oroszlánok megfigyeléséből származik, midőn azok mancsaikkal sziklákat görgettek. Az MAN (M.A.N.: Maschinenfabrik Augsburg-Nürnberg) jármüvek hütőrácsának dísze esetén az üzenet már jóval világosabb: „Erös, mint egy oroszlán” (6.c ábra). A stilizált braunschweigi oroszlánt, ami eredetileg Henrik szász herceg címerállata volt, a 70-es évek elején beolvasztott Büssing cég 1913-ban használta először teherautóin.

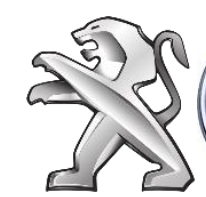

a)

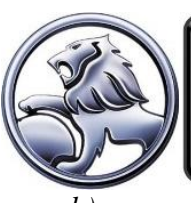

b)

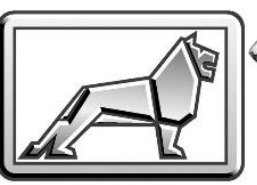

c)

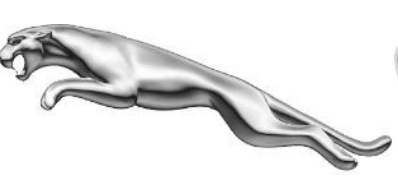

d)

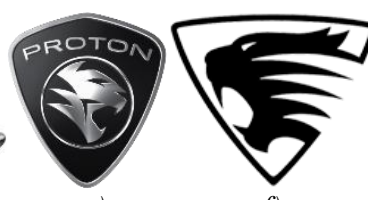

f)

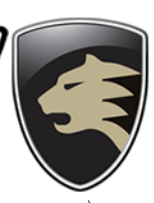

g)

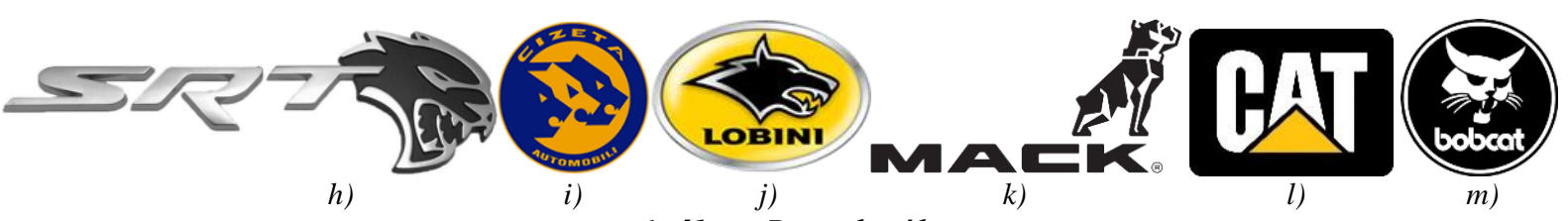

6. ábra. Ragadozók

A sportosan elegáns autóiról ismert Jaguar agresszívebb üzenettel inspirálja a vásárlót, ugyanis már a Dél- és Közép-Amerika őslakosaitól eredő szó jelentése is: „ami egy ugrással leterit”. A támadó jaguárt ábrázoló szimbólum ezt az érzést szavak nélkül is egyértelmüen magában hordozza (6.d ábra). A nagymacskáknál maradva a 6.e-f-g ábrákon három egymáshoz nagyon hasonló embléma követi egymást. A malajziai Proton autóin egy üvöltő maláj tigris látható, a dél-koreai Spirra szupersportautók emblémájának fö motívumát egyszerüen csak háromszögben ordító nagymacskafejként azonosítják, míg a $9 f f$ nevü, Porsche sportautók átépítésére specializálódott német tuning cég fekete pajzson arany macskát alkalmaz átépített autóin. Az érintett cégek esetén nem kell egymás kölcsönös és tudatos másolására gondolni. Inkább a legtöbbünk által a házi macskáktól is jól ismert jellembeli tulajdonságok miatt használ több vállalat is ilyen jelképeket. Chrysler, Dodge és Jeep autók gyári teljesítményfokozásával foglalkozik a Fiat Chrysler Automobiles csoport Street \& Racing Technology részlege. Az SRT jelzésen felül a 6.h ábrán látható egyedi logóval is jelzik, ha Hellcat motort építettek az adott jármübe.

A ragadozókon belül maradva, de a macskafélék családjáról áttérve a kutyafélékre már jóval szükebb a lista. Ez már csak azért is meglepő, mert a kutyákhoz leggyakrabban társított tulajdonság a hüség, ami egy autó esetén is pozitív érték lehet. A legismertebb vad kutyaféle a farkas viszont a ragadozók által képviselt minden tulajdonságot magában hordozza, de emellett a csapatszellem, a fegyelem és rendezettség fogalmai is köthető hozzájuk. Az ókori mondavilágban is szerepet kaptak, 
mivel a Rómát később alapító Romulust és Remust egy nőstényfarkas táplálta. Épp ezt a farkast választotta jelképének az egyedi autókat készítő modenai székhelyủ olasz Cizeta autóépítő mühely [8]. A brazil, Audi motoros, üvegszálas karosszériájú sportkocsikat gyártó Lobini logójában viszont sokkal jobban felismerhető a farkasfej, aminek éles vonalai az agressziót tükrözik, szük szemnyílása pedig felidézi a farkasokat övező misztériumokat.

A valódi, megszelídített kutya motívuma még ennél is ritkább. Próbálkozásként említhető meg az 1927-es Lincoln autókon rövid időre feltünő ugró agár, ami a sebességet, kitartást és szépséget idézte, viszont semmilyen hatást nem gyakorolt a márka későbbi emblémáira. A legismertebb ma is létező kutyás autólogó az amerikai Mack teherautók jelképe a gazdája parancsát váró, cselekvésre kész testtartásban ábrázolt bulldoggal (6.k ábra). Csak érdekességként szerepel 6.l ábrán a Caterpillar munkagépek rövidített logója, ami miatt az építőiparban „cat” azaz macska néven emlegetik. A névadó azonban egy egészen más állat, ugyanis a cég alapítója, Benjamin Holt volt a "hernyótalpas" traktor feltalálója így innen ered a "caterpillar" elnevezés, hiszen a szó angolul hernyót jelent. A Bobcat viszont a márkanév eredeti jelentését tekintve és a logó fö motívumát nézve is amerikai hiúzt ábrázol.

\subsection{Mitológiai lények}

A mondák, mítoszok és mesék lényei mindig egy vagy több állat testfelépítését ötvözik azzal a célzattal, hogy valós élőlények valamely tulajdonságát felerösítsék vagy egyesítsék. Ilyen a griff is, amit minden teremtmény urának, az isteni hatalom jelképének tekintettek. Az állatok királyának oroszlán testével és a levegő urának mondott sas fejével és szárnyaival felvértezve lesz belőle a felemelkedett erőt megtestesítő szárnyaló oroszlán. Egyes vélekedések szerint a griff a mitológiai lények körében egyfajta sárkány hibrid, mert zoomorf vagyis állat alkatú.

Az uralmi hatást tovább fokozza a koronás griff-fej a svéd Saab és Scania logóin (7.a-bábra). Előbbi a személygépkocsi utóbbi pedig a teherautó üzletág neve, de az embléma fó motívuma teljesen megegyezik. A 90-es évektől az Opel jobbkormányos változatai a tulajdonos $G M$ egyedi üzletpolitikája miatt az általános autóipari gyakorlattól eltérően azonos típusmegnevezésekkel, de eltérő márkanév alatt kerülnek forgalomba (7.c ábra). A korábban független gyártó a Vauxhall márkajelzésén egy „V” betüs zászlót tartó griff szerepel, ami arra utal, hogy a cég gyártmányai olyan kincsek, mint amiket ezek a misztikus lények mindig is őriztek. A német alapítású Gumpert szupersportkocsikat gyártó cég jelvénye még dinamikusabb formában, felszálláshoz való elrugaszkodás közben hátsó lábain álló griffmadarat ábrázol. Az ő olvasatukban az egyediség mellett autóik ezen mitikus lény fékezhetetlenségét és erejét idézik. Márpedig a legendák szerint hatalomban és agilitásban kevesen tudnak versenyre kelni egy griffel.

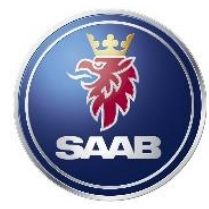

a)

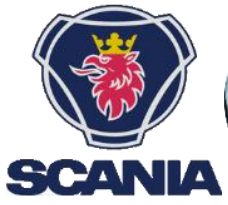

b)

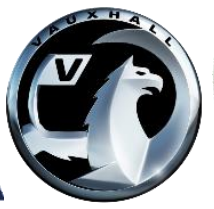

c)

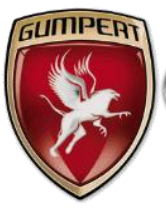

d)

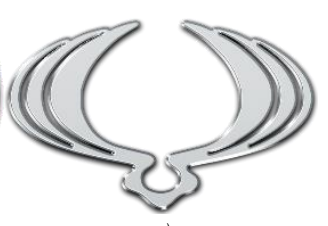

e)

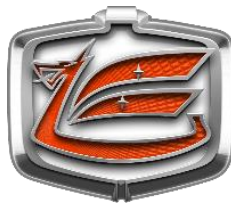

f)

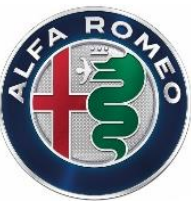

g)

Hasonlóan viszonyul az emberiség a sárkányokhoz, amiknek a Távol-Keleten van igazán nagy kultusza. A sárkány legtöbbször hatalmas teremtő erővel bíró pozitív lény, ami képviseli a bölcsességet és a védelmet is. Magába foglalja az összes őselemet, sőt egyes megközelítések szerint a sárkány maga a természet. Nem meglepő tehát, hogy Dél-Korea legrégebbi autógyártója, a Ssangyong logójában is feltünik. Már maga a márkanév is ikersárkányt jelent, az embléma pedig az égbe 
emelkedő két összefonódó sárkány stilizált ábrázolása (7.e ábra). Ennél egyértelmübb sárkánymotívum található a Toyota Celica sportautóinak első két generációján. Bár egyes autótulajdonosok szerint egy sárkány-árbócos viking hajót mintáz a jelvény (7.fábra). Ennek ellentmond, hogy nem tudunk viking kapcsolatokról a japán nép történelmében, viszont kultúrájukban a sárkányok kiemelt helyet foglalnak el. A 7.g ábrán egy úgyszintén többféle értelmezéssel bíró, de történetét tekintve mégis lekövethetőbb embléma látható. Az olasz Alfa Romeo jelvényének zöld lénye helyenként kígyó, máshol sárkány, de talán a koronás, sárkányfejủ kígyó áll legközelebb a valósághoz. A félreértésre az alapul vett történelmi téma ad magyarázatot, mivel maga a sárkány a várost a 14. században irányító Visconti család címeréből származik, ami többszöri átértelmezésen esett át az idők folyamán. A kevésbé tájékozott fogyasztók talán ezért is többnyire lángnyelveket lövellő szörnyet látnak az emblémán, holott az egy sárkány szájából megtisztulva kiszabaduló új embert szimbolizál. A gyártó milánói kötődését mutatja székhelyének szimbóluma, a piros kereszt is.

\subsection{Kérődzők}

Ezen alkategória elnevezése furcsának tünhet, de ez azért van, mert maga a csoport is az. Növényevőkkel már találkoztunk a lovak esetében, ahol a kötődés az emberhez, a szabadság és a sebesség volt az emblémák legföbb szimbolikája. A kérődzők csoportjára ez már nem mondható el. Az ide sorolt állatok ebben a megközelítésben közelebb állnak a ragadozókhoz, hiszen ugyanúgy a vadság és a zabolázatlan erő megtestesítői.

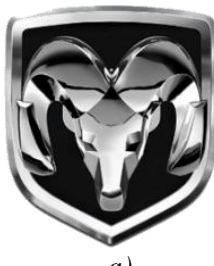

a)

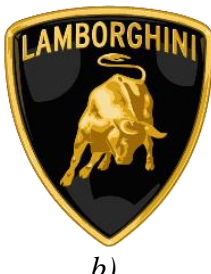

b)

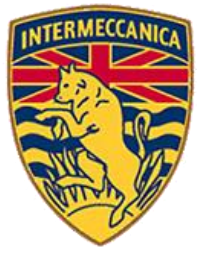

c)

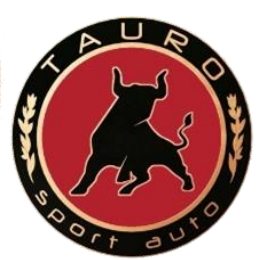

d)

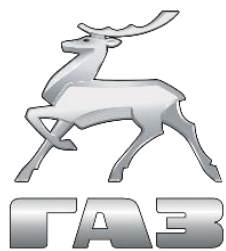

e)

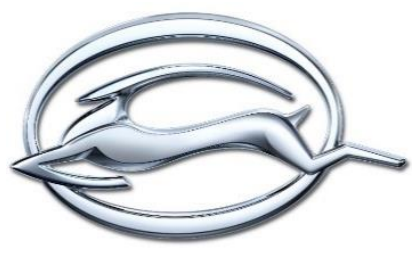

f)

8. ábra. Kérödzök, az ösvények királyai

A 8. a ábra a korábban Dodge autókon látható emblémát mutatja. Napjainkban a Chrysler csoport 2010-es átszervezésével önálló márkává vált $\boldsymbol{R A} \boldsymbol{M}$ gyártmányok kapják kizárólag ezt a kosfej szimbólumot. Maga a szójáték is találó ezeknél a robosztus pick-up-oknál. Hiszen mi jut az eszünkbe, ha szembe jön az ösvények királya, egy kos (angolul: ram)? Az, hogy „kitérni” (angolul: dodge). Szavak nélkül is ezt közvetíti a pajzson elhelyezett, tiszteletet követelő térbeli kos fej. Ugyanezt az erős dominanciát képviselik a bikák is. A legismertebb ilyen autós embléma a Lamborghini sportkocsikon öklelni készülö, feldühödött arany bika, ami szintén jó választásnak tünik, hiszen éppen ezt az érzést várják a vásárlók is egy drága, nagy teljesítményü jármütől. Az olasz cég egyébként eredetileg traktorokat gyártott, így a mezőgazdaságban tevékenykedő vásárlóitól az alapító Ferruccio Lamborghini jól ismerte a bikák általános természetét. A márkajelzésen viszont egy konkrét állat, Murciélagó képe szerepel, hiszen ez a legendás bika 1879-ben egy viadalon 24 kardszúrást élt túl, és ezzel az erő meghatározó szimbóluma lett. A szintén olasz alapítású, de történetét tekintve több nemzethez is köthető Intermeccanica ágaskodó bika motívumát jelenleg az elektromos törpeautókat gyártó kanadai Meccanica utódvállalat birtokolja és használja. Marketing-kommunikációjukban ez a cég tradíciójából származó büszkeséget jelképezi. A bikaviadalokhoz legközelebb a spanyolok állnak, így nem meglepő, hogy a luxussportkocsik építésével foglalkozó Tauro logóján is egy célpontját kiszemelő, támadni készülő bika sziluettje szerepel. 
A vad és támadó kérődzőkkel szemben sokkal inkább a méltóságteljességet, fenséget és érettséget szimbolizálja a szarvasbika. A számos kultúrában - köztük a magyar mondavilágban is - fontos jelentéstartalommal bíró állat egyszerre testesíti meg az idő periodicitását és a megújulást, a jóságot, a kiforrottságot vagy helyenként magát a férfiasságot is, míg a keleti népeknél egyet jelent a jóléttel és hosszú élettel. A 2.3 alfejezet 5.g ábráján már említettük a szarvasagancsokat a Porsche esetében, ahol az mindössze csak egy utalás a cég székhelyére. A GAZ (Gorkovsky Avtomobilny Zavod) orosz autógyár esetében azonban már egy büszkén álló szarvasbika sziluettje adja a logó főmotívumát. A vállalat ez esetben is az állat tartásából sugárzó erőt vonatkoztatja pl. Ford licensz alapú gyártmányaira. Érdekesség, hogy a haszongépjármüveinek márkaneve GAZelle, ami szintén egy párosujjú patás faj megnevezése. De nem ez az egyetlen antilopfaj, ami megihlette a gyártókat. A Chevrolet Impala névválasztásával és a 8.fábrán bemutatott egyedi emblémájával is az afrikai impalák mozgására jellemző kecsességet, dinamizmust és gyorsulás sugallja.

\subsection{Csúszómászók}

Az utolsó nagy csoportba sorolható minden olyan állat, ami nem fért bele az előzőek egyikébe sem. Legtöbbször ezek az élőlények nem tartoznak az emberek kedvencei közé, viszont egyes tulajdonságaik miatt a csodálat, félelem vagy kíváncsiság érzését keltik a szemlélöben. Itt is érdemes megemlíteni, hogy például egy teljes autókategória viseli az ízeltlábúak törzsébe sorolható pókok rendjének elnevezését. A gyártónként, de olykor még azon belül is eltérő fonetikával használt Spider vagy Spyder nevet használják a könnyü, kétüléses, nyitott sportautók típus-megnevezéseként. Vagyis a hagyományos zárt karosszériás sportkocsik nyitható tetős változatai gyakran kapják ezt a megkülönböztető jelzést. Az alapgondolat onnan eredhet, hogy ezen járművek rossz időjárás esetén felkerülő tetői ezeket a kisutókat egyesek szemében a pókhoz hasonlóvá teszik.

A hivatalos gyári emblémáknál maradva a kígyó említhető, mint olyan visszatérő motívum, ami többször megjelenik, holott a kígyó legtöbbször negatív figura. A világ egészére kiható keresztény kultúrkörben például a csábítást szimbolizálja. Ehhez kötődően vált a végzet megtestesítőjévé, míg helyenként az örök igazság üzenethordozója. A kígyóméreg gyógyításban betöltött szerepe miatt viszont a kígyók egyben a bölcsesség és tudomány nemzetközileg ismert szimbólumai is.

A 9.a ábra szolgáltatja az első konkrét példát. A Dodge Viper emblémáján ugyanis a sportautó névadója, egy vipera képe jelenik meg. A viperafélék családja egy meglehetősen sok fajt tömörítő csoport, számos emberre is veszélyes mérgủ változattal. Emiatt a név világszerte ismert, így kiváló „reklámarca” lehet egy versenypályákon is bizonyítani képes, „felhúzott” sportkocsinak. A 9.b ábrán már a Shelby American vállalat által feltuningolt szériaautók nagy teljesítményü sportautóin megjelenő kobra embléma látható. A föként Ford Motor Company gyártmányok teljesítményfokozásával foglalkozó cég első munkája az AC Cobra volt. Ezen roadster sikereit viszi tovább a szétterpesztett nyaki lebenyével figyelmet követelö, sokak szerint az állatvilág legkülönlegesebb kígyóját mintázó embléma.

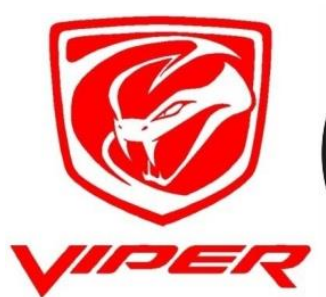

a)

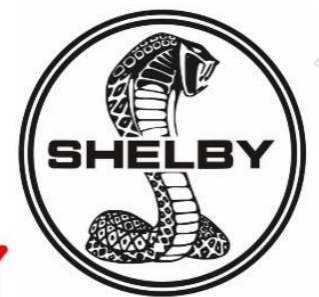

b)

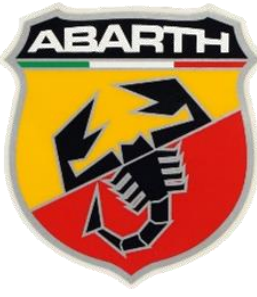

c)

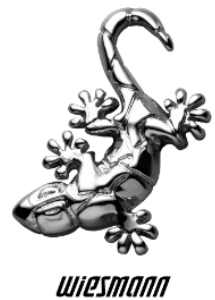

d)

9. ábra. Hüllők és izeltlábúak az autóemblémákon 
A kígyók mellett az ízeltlábúak is képviseltetik magukat az autóemblémákon. Ismét egy méreggel rendelkező állat szolgáltatja az alapot a Fiat tuninggal foglalkozó Abarth cég pajzs alakú logóján. A sárga és vörös szín mellett a jól felismerhető részletességgel ábrázolt fekete skorpió is a még hangsúlyosabb figyelemfelkeltés szolgálja. A különleges testfelépítésü skorpió egyet jelent az egyediséggel és a veszéllyel. Azt üzeni, hogy minden porcikája harcra termett. Az embléma Karl (később Carlo) Abarth születési csillagjegyéből származik, de az egyértelmü marketing értelmezés sem marad el. Az Abarth gépkocsik jól kezelhetőek, erőteljesek és nagyteljesítményüek kell legyenek, de mindenekelőtt kisméretüek és "rosszak", mint egy skorpió.

Végül egy gerinces állat is képviselteti magát ebben a kategóriában. Teljesen tudatosan választotta a Wiesmann német egyedi sportautógyártó jelképéül a gekkót. Ezen a gyíkok alrendjébe sorolható család tagjainak mozgásához közismerten kötődik az egyedülálló tapadás és jó manőverezés. A gyártó éppen ezt ígéri. Vállalásuk, hogy autóik képesek extrém gyorsan mozogni bármilyen felületen, hiszen „A Wiesmann autói tapadnak az úthoz”, ezért jól irányíthatók nagy sebességnél is.

\section{3. Összefoglalás}

A márkajelek legfontosabb feladata, hogy értéket közvetítenek. Összességében elmondható, hogy a természetből átemelt figurákkal felidézhetjük az ahhoz társított kollektív tudást. Legtöbb esetben az ilyen motívumok ismerősnek hatnak és időtállóságot sugallnak és ezzel is a megbízhatóság érzetét keltik. Ezek a tulajdonságok a vásárlók szemében mindig fontos szempontok lesznek, tehát a természet felidézése marketing szempontból is célravezetö, hiszen egyrészt segíti a kívánt üzenet átadását, másrészt pedig javítja az embléma megjegyezhetőségét is.

\section{Köszönetnyilvánítás}

A cikkben ismertetett kutatómunka az EFOP-3.6.1-16-2016-00011 jelü „Fiatalodó és Megújuló Egyetem - Innovatív Tudásváros - a Miskolci Egyetem intelligens szakosodást szolgáló intézményi fejlesztése" projekt részeként - a Széchenyi 2020 keretében - az Európai Unió támogatásával, az Európai Szociális Alap társfinanszírozásával valósul meg.

\section{Irodalomjegyzék}

[1] Heptinstall, S.: Car Marques: A Graphic Guide to Automotive Logos and Emblems, Motorbooks, 2018, ISBN: 0760362457

[2] Wheeler, A.: Designing Brand Identity, John Wiley \& Sons, Inc. 2009, ISBN 0470401422

[3] Budelmann, K.: Brand Identity Essentials, Rockport Publishers, 2010, ISBN: 1592535781

[4] Orgoványi, G.: Design és tipográfiai alapok, Tervezőgrafika II. tananyag, 2010 http://centroszet.hu/tananyag/tervgrafika2/212_a_renault_log_trtnete.html

[5] Dömötör, Cs., Péter, J.: Természeti elvek az analógia alapú tervezésben, GÉP, Vol. 63, No. 12. ISSN 00168572, Miskolc, 2012. november, pp. 29-32.

[6] Négyesi, P.: Autóépítés Magyarországon 1945-1990, 2011, ISBN: 978-9630977012, www.magyarjarmu.hu

[7] MTI - Itt vannak a Komondorok, az új magyar harcjármüvek, HVG Kiadó, 2015. október. 14., EPA-00332 https://hvg.hu/itthon/20151014_Itt_a_Komondor_az_uj_magyar_harcjarmu_f

[8] https://cizetaautomobile.com/supercar/[8]

[9] https://listcarbrands.com

[10] http://automarkak.theboard.hu/auto-emblemak 